\title{
PERBEDAAN EFEKTIFITAS FOOT MASSAGE DAN PROGRESSIVE MUSCLE RELAXATION TERHADAP PENURUNAN TEKANAN DARAH DAN KECEMASAN PENDERITA HIPERTENSI
}

$$
\text { Gustini }^{1^{*}}, \text { Djunizar Djamaludin }^{2}, \text { Rika Yulendasari }^{3}
$$

1,2,3Program Studi Ilmu Keperawatan Universitas Malahayati Bandar Lampung E-mail Koresponden: gustinilpg@gmail.com

\section{ABSTRACT: THE DIFFERENCE OF FOOT MASSAGE AND PROGRESSIVE MUSCLE RELAXATION EFFECTIVENESSON REDUCTION OF BLOOD PRESSURE AND ANXIETY OF HYPERTENSION}

Background : Hypertension is persistent blood pressure with systolic pressure above $140 \mathrm{mmHg}$ and diastolic pressure above $90 \mathrm{mmHg}$. According to WHO (World Health Organization) hypertension cases in the world has increased and on 2025 will be about 1.5 billion people. In the working of Ogan Lima Community Health Centre of North Lampung on 2019, hypertension placed the fifth rank with 19 hypertension people. The previous study obtained the result that most of people with hypertension did not know about nonpharmacologic therapy to ease hypertension such as foot massage and progressive muscle relaxation (PMR).

Method : This research is quantitative with two groups with intervention design. The population in this research was hypertension patients in medical record of Ogan Lima Community Health Centre with a sample of 18 respondents. Data analysis using paired T-Test and independent T-Test.

Result : This research result showed blood pressure of systole and diastole result before therapy was $P$-value 0,866 and 0,618 , systole and diastole value after therapy was $p$ value 0,764 and 0,346 , anxiety level before therapy was $p$ value 0,567 and anxiety level after therapy was $p$ value 0,913 .

Conclusion : There was no different effectivity before therapy on reduction of blood pressure ( $p$ value 0,866 and 0,618 ), there was no different effectivity after therapy on reduction of blood pressure ( $p$ value 0,567$)$, and there was no different effectivity after therapy on anxiety ( $p$ value 0,913$)$.

Keywords : Foot Massage; Progressive Muscle Relaxation; Blood Pressure; Anxiety; Hypertension

\section{INTISARI: PERBEDAAN EFEKTIFITAS FOOT MASSAGE DAN PROGRESSIVE MUSCLE RELAXATION TERHADAP PENURUNAN TEKANAN DARAH DAN KECEMASAN PENDERITA HIPERTENSI}

Pendahuluan : Hipertensi adalah tekanan darah persisten dengan tekanan sistolik diatas $140 \mathrm{mmHg}$ dan tekanan diastolik diatas $90 \mathrm{mmHg}$. Menurut WHO (World Health Organization) penderita hipertensi di dunia terus bertambah dan pada tahun 2025 diperkirakan meningkat menjadi 1,5 miliar orang. Di Wilayah Kerja Puskesmas Ogan Lima Kabupaten Lampung Utara pada tahun 2019 hipertensi menempati urutan kelima dengan jumlah penderita 819 orang. Studi pendahuluan mendapatkan hasil bahwa banyak pasien hipertensi yang belum mengetahui terapi nonfarmakologis untuk mengatasi hipertensi seperti foot massage dan progressive muscle relaxation (PMR). 
Metode :Penelitian ini adalah penelitian kuantitatif dengan pendekatan two groups with intervention design. Populasi dalam penelitian ini adalah pasien yang terdiagnosa hipertensi dalam rekam medik Puskesmas Ogan lima dengan jumlah sampel 18 responden. Analisa data yang digunakan menggunakan uji statistik paired T-Test dan independent T-Test.

Hasil : Hasil penelitian ini menunjukan tekanan darah nilai sistole dan diastole sebelum terapi adalah $p$ value 0,866 dan 0,618 , nilai sistole dan diastole setelah terapi adalah $p$ value 0,764 dan 0,346 , tingkat kecemasan sebelum terapi dengan $p$ value 0,567 , dan tingkat kecemasan setelah terapi dengan $p$ value 0,913 .

Simpulan : Tidak ada perbedaan efektifitas sebelum diberikan terapi terhadap penurunan tekanan darah ( $p$ value 0,866 dan 0,618 ), Tidak ada perbedaan efektifitas setelah diberikan terapi terhadap penurunan tekanan darah ( $p$ value 0,764 dan 0,346), Tidak ada perbedaan efektifitas sebelum diberikan terapi terhadap tingkat kecemasan ( $p$ value 0,567$)$, dan tidak ada perbedaan efektifitas setelah diberikan terapi terhadap tingkat kecemasan ( $p$ value 0,913 ).

Kata Kunci: Foot Massage; Progressive Muscle relaxation; Tekanan Darah; Kecemasan; Hipertensi

\section{PENDAHULUAN}

Hipertensi merupakan silent killer dimana gejala dapat bervariasi pada masing-masing individu dan hampir sama dengan gejala penyakit lainnya. Gejalagejalanya itu adalah sakit kepala/rasa berat di tengkuk, pusing (vertigo), jantung berdebardebar, mudah lelah, penglihatan kabur, telinga berdenging (tinnitus), dan mimisan (Khairani \& Fadhila, 2015).

Berdasarkan data WHO ((World Health Organization) pada tahun 2015, penderita hipertensi di dunia yaitu sekitar 1,13 miliar orang. Diperkirakan pada tahun 2025, jumlah orang yang mengalami hipertensi di dunia akan terjadi peningkatan secara terus-menerus setiap tahunnya yaitu akan ada penderita hipertensi sejumlah 1,5 miliar orang. Orang-orang yang meninggal akibat hipertensi dan komplikasi diperkirakan akan terus bertambah sekitar ada 9,4 juta orang setiap tahun. pada tahun 2013 prevalensi hipertensi di Indonesia adalah 25,8\% dan pada tahun 2018 jumlahnya meningkat menjadi 34,1\% (Riskesdas, 2018).
Kecemasan (ansietas/anxiety) adalah gangguan alam perasaan (affective) yang ditandai dengan perasaan ketakutan atau kekhawatiran yang mendalam dan berkelanjutan. Di Indonesia jumlah yang menderita gangguan kecemasan ini baik akut maupun kronik mencapai 5\% dari jumlah penduduk, dengan perbandingan antara wanita dan pria sebesar 2 berbanding 1 dan diperkirakan antara 2 - 4\% di antara penduduk di suatu saat dalam kehidupannya pernah mengalami gangguan cemas (Indrajaya, 2018).

Penanganan hipertensi dan kecemasan dilakukan dengan dua cara yaitu secara farmakologis dan nonfarmakologis.Secara terapi farmakologis dapat digunakan obatobatan antihipertensi, tetapi terapi farmakologis ini dapat menimbulkan efek samping berupa mual, muntah, pusing, takikardi dan palpitasi yang berbahaya pada tubuh. Sedangkan secara nonfarmakologis banyak terapi individual yang bisa diterapkan berupa diet, olah raga, meditasi dan terapi relaksasi (Putri \& Amalia, 2019). 
Salah satu terapi non farmakologis yang ditawarkan untuk menurunkan hipertensi yaitu terapi foot massage (pijat kaki) dan Progressive Muscle Relaxation (PMR). Foot Massage adalah manipulasi jaringan ikat melalui pukulan, gosokan atau meremas untuk memberikan dampak pada peningkatan sirkulasi, memperbaiki sifat otot dan memberikan efek relaksasi. Foot Massage mampu memberikan efek relaksasi yang mendalam, mengurangi kecemasan, mengurangi rasa sakit, ketidaknyamanan secara fisik, dan meningkatkan kualitas tidur pada seseorang. Saat kaki dipijat energi akan diproduksi dalam tubuh dan aliran darah menjadi lancar sehingga memudahkan aliran energi dalam tubuh (Yumni \& Holidah, 2018).

Progressive Muscle Relaxation (PMR) yaitu proses yang dapat melepaskan ketegangan dan mengembalikan keseimbangan baik pikiran maupun tubuh. Apabila teknik ini dilakukan pada pasien yang memiliki tekanan darah tinggi, mereka akan benar-benar merasa rileks sehingga dapat membantu meningkatkan kualitas tidur dan mengontrol peningkatan tekanan darah, karena dengan cara mengendurkan otot-otot secara sengaja akan membuat suasana hati menjadi lebih tenang dan juga lebih santai. Relaksasi otot progresif dipandang cukup praktis dan ekonomis dibandingkan terapi yang lain karena tidak memerlukan imajinasi yang rumit, tidak ada efek samping, mudah dilakukan, tidak memerlukan biaya dan bisa membuat tubuh dan pikiran menjadi tenang, rileks dan lebih mudah untuk tidur (Lestari \& Yuswiyanti, 2018).

Angka kejadian Hipertensi di Puskesmas Ogan Lima pada tahun 2019 yaitu sebanyak 819 orang dari
19.063 jumlah penduduk tetapi pada tahun 2019 mengalami kenaikan yang signifikan dibandingkan dengan tahun 2018 yaitu sebanyak 40\% dan pada triwulan 1 sampai 4 di tahun 2019 penderitanya terus menerus bertambah tanpa mengalami penurunan. Selain itu juga banyak penderita hipertensi yang tidak menkonsumsi obat antihipertensi dengan berbagai alasan dan banyak penderita hipertensi dan kecemasan yang belum mengetahui manfaat teknik relaksasi untuk menurunkan tekanan darah dan kecemasan (Dinas Kesehatan Lampung Utara, 2019).

Dari pemaparan tersebut maka tujuan penelitian ini adalah untuk mengetahui perbedaan efektifitas foot massage dan progressive muscle relaxation terhadap penurunan tekanan darah dan kecemasan pada penderita hipetensi.

\section{METODOLOGI PENELITIAN}

Jenis penelitian yang digunakan yaitu penelitian quasi experiment. Desain penelitian yang digunakan yaitu two groups with intervention design. Desain penelitian ini dengan membagi 2 kelompok yaitu kelompok intervensi foot massage dan kelompok progressive muscle relaxation. Populasi pada penelitian ini adalah pasien yang terdiagnosa hipertensi berdasarkan catatan rekam medik Puskesmas Ogan Lima. Sampel yaitu pasien hipertensi yang juga mengalami kecemasan yang diberikan intervensi foot massage sebanyak 9 orang dan diberikan intervensi Progressive Muscle Relaxation (PMR) sebanyak 9 orang sehingga total sampel sebanyak 18 responden.

Teknik sampling yang digunakan yaitu purposive sampling dengan kriteria inklusi; Bersedia 
menjadi responden penelitian; Responden yang terdiagnosa hipertensi berdasarkan catatan rekam medis Puskesmas; Pasien hipertensi dengan sistolik $\geq 140$ $\mathrm{mmHg}$ dan/atau diastolik $\geq 90$ $\mathrm{mmHg}$; Pasien Hipertensi dengan dengan kecemasan Ringan (Skor 1420); Pasien Hipertensi dengan dengan kecemasan sedang (Skor 2127); Responden mampu berkomunikasi dengan baik dan mengerti instruksi.

Pengumpulan data dilakukan pada tanggal 3 Juni 2020 sampai 20 Juni 2020 di wilayah kerja Puskesmas Ogan Lima Kabupaten Lampung Utara dengan cara kedua kelompok pada hari pertama diukur tekanan darah menggunakan Sphygmomanometer dan stetoskop kemudian diukur tingkat kecemasan menggunakan kuesioner
HARS. Kelompok pertama diberikan intervensi foot massage dan kelompok kedua diberikan intervensi progressive muscle relaxation selama 7 hari berturutturutdengan durasi setiap intervensi 15 menit sampai 20 menit kemudian pada hari ketujuh diukur kembali tekanan darah dan kecemasan untuk mengetahui perubahan tekanan darah dan tingkat kecemasan.

Pengumpulan data dan pada saat melakukan intervensi foot massage dan intervensi progressive muscle relaxation, dilakukan dengan tetap memperhatikan protokol kesehatan selama menghadapi pandemi Covid-19 antara lain; memakai masker; menjaga jarak minimal 1,5 meter; rajin mencuci tangan dan mengunakan hand sanitiz.

\section{HASIL PENELITIAN}

\section{Analisis Univariat}

Tabel 1. Karakteristik Responden Berdasarkan Usia, Jenis Kelamin, Genetik, Obesitas, Merokok dan Minum kopi di Wilayah Kerja Puskesmas Ogan Lima Kabupaten Lampung Utara

\begin{tabular}{|c|c|c|c|c|}
\hline \multirow{3}{*}{ Usia (Tahun) } & \multicolumn{4}{|c|}{ Responden } \\
\hline & \multicolumn{2}{|c|}{ Foot Massage } & \multicolumn{2}{|c|}{$\begin{array}{c}\text { Progressive Muscle } \\
\text { Relaxation }\end{array}$} \\
\hline & Jumlah & $\begin{array}{c}\text { Persentase } \\
\text { (\%) }\end{array}$ & Jumlah & $\begin{array}{l}\text { Persentase } \\
\text { (\%) }\end{array}$ \\
\hline $40-49$ & 2 & 22,2 & 2 & 22,2 \\
\hline $50-54$ & 4 & 44,4 & 5 & 55,6 \\
\hline $55-59$ & 2 & 22,2 & 2 & 22,2 \\
\hline $60-65$ & 1 & 11,1 & 0 & 0,0 \\
\hline Total & 9 & 100,0 & 9 & 100,0 \\
\hline \multicolumn{5}{|l|}{ Jenis Kelamin } \\
\hline Laki-laki & 3 & 33,3 & 3 & 33,3 \\
\hline Perempuan & 6 & 66,7 & 6 & 66,7 \\
\hline Total & 9 & 100,0 & 9 & 100,0 \\
\hline \multicolumn{5}{|c|}{ Genetik Hipertensi } \\
\hline Ya & 8 & 88,9 & 6 & 66,7 \\
\hline Tidak & 1 & 11,1 & 3 & 33,3 \\
\hline Total & 9 & 100,0 & 9 & 100,0 \\
\hline \multicolumn{5}{|l|}{ Obesitas } \\
\hline $\mathrm{Ya}$ & 0 & 0 & 0 & 0 \\
\hline Tidak & 9 & 100,0 & 9 & 100,0 \\
\hline
\end{tabular}




\begin{tabular}{ccccc} 
Total & 9 & 100,0 & 9 & 100,0 \\
\hline Merokok & & & & \\
Ya & 4 & 44,4 & 3 & 33,3 \\
Tidak & 5 & 55,6 & 6 & 66,7 \\
Total & 9 & 100,0 & 9 & 100,0 \\
\hline Minum kopi & & & & \\
Ya & 6 & 66,7 & 2 & 22,2 \\
Tidak & 3 & 33,3 & 7 & 77,8 \\
Total & 9 & 100,0 & 9 & 100,0 \\
\hline
\end{tabular}

Dari tabel 1 diatas, dapat dilihat jumlah responden dengan usia terbanyak pada kelompok 1 adalah pada rentang 50-54 tahun sebanyak 4 responden ( $44,4 \%)$ dan pada kelompok kedua juga pada rentang 50-54 tahun sebanyak 5 responden (55,6\%). Berdasarkan jenis kelamin responden terbanyak pada kelompok 1 dan 2 adalah perempuan dengan jumlah yang sama yaitu 6 orang $(66,7 \%)$. Responden dengan genetik hipertensi pada kelompok pertama sebanyak 8 respoden $(88,9 \%)$ dan pada kelompok kedua sebanyak 6 orang $(66,7)$. Pada kelompok 1 dan 2 tidak ada responden yang mengalami obesitas (0,0\%). Berdasarkan kebiasaan merokok pada kelompok 1 ada 4 orang yang merokok $(44,4 \%)$ dan pada kelompok 2 ada 3 orang yang merokok (33,3\%). Berdasarkan kebiasaan minum kopi pada kelomok pertama ada 6 orang yang minum kopi $(66,7 \%)$ dan pada kelompok 2 hanya ada 2 orang yang punya kebiasaan minum kopi $(22,2 \%)$.

Tabel 2

Distribusi Rata-Rata Nilai Tekanan Darah Sebelum Dan Sesudah Diberikan Terapi Foot Massage dan Progressive Muscle Relaxation di Wilayah Kerja Puskesmas Ogan Lima Kabupaten Lampung Utara Tahun 2020

\begin{tabular}{cccc} 
& & & $\mathrm{n}=\mathbf{1 8}$ \\
\hline Kelompok & TD & Mean \pm SD & Min - Max \\
\hline Pre test foot massage & Sistole & $153,33 \pm 14,142$ & $140-180$ \\
& Diastole & $101,11 \pm 10,541$ & $90-120$ \\
Post test foot & Sistole & $145,56 \pm 16,667$ & $120-170$ \\
massage & Diastole & $91,11 \pm 10,541$ & $80-110$ \\
Pre test progressive & Sistole & $154,44 \pm 13,333$ & $140-180$ \\
muscle relaxation & Diastole & $98,89 \pm 7,817$ & $90-110$ \\
Post test progressive & Sistole & $143,33 \pm 14,142$ & $120-170$ \\
muscle relaxation & Diastole & $95,56 \pm 8,819$ & $80-110$ \\
\hline
\end{tabular}

Berdasarkan tabel 2 terlihat bahwa sebagian besar penderita gagal jantung mengalami kelelahan berat sebanyak 11 responden $(73,3 \%)$ dan responden yang mengalami kelelahan ringan sebanyak 4 orang $(26,7 \%)$. Hal ini sesuai dengan teori bahwa gejala dari penyakit gagal jantung adalah keletihan atau kelelahan terusmenerus sepanjang hari (Majid, 2017). Kelelahan pada pasien gagal jantung disebabkan oleh gangguan neurohormonal yang terjadi akibat kegagalan mempertahankan jantung (Nugraha, Fatimah, E Kurniawan, 2017). 
Tabel 3. Rata-Rata Nilai Tingkat Kecemasan Sebelum Dan Sesudah Diberikan

Terapi Foot Massage dan Progressive Muscle Relaxation di Wilayah Kerja Puskesmas Ogan Lima Kabupaten Lampung Utara Tahun 2020

\begin{tabular}{ccc} 
& $\mathbf{n}=15$ \\
\hline Kelompok & Mean \pm SD & Min - Max \\
\hline Pre test foot massage & $19,67 \pm 5,099$ & $14-27$ \\
Post test foot massage & $15,56 \pm 5,102$ & $8-22$ \\
Pre test progressive muscle & $18,44 \pm 3,644$ & $14-25$ \\
$\begin{array}{c}\text { relaxation } \\
\text { Post test progressive muscle } \\
\text { relaxation }\end{array}$ & $15,78 \pm 3,232$ & $10-20$ \\
\hline
\end{tabular}

Berdasarkan tabel 3 diketahui bahwa sebelum diberikan Terapi Emotional Freedom Technique (EFT) rata-rata tingkat kelelahan penderita gagal jantung sebesar 21,27 dengan standar deviasi 9,384. Hal ini berarti bahwa pasien gagal jantung di Puskesmas hanura mengalami kelelahan berat sehingga mengganggu aktivitas sehari-hari. Tingkat kelelahan pasien gagal jantung sesudah terapi EFT sebesar 26,40 dengan standar deviasi 8,41. Hal ini berarti bahwa rata-rata penderita gagal jantung Puskesmas Hanura mengalami penurunan tingkat kelelahan tetapi masih mengalami kelelahan berat.
Hasil ini sesuai dengan penelitian Nugraha (2017) yang menyatakan bahwa teknik relaksasi merupakan intervensi keperawatan yang dilakukan untuk mengatasi masalah terutama akibat respon saraf simpatis. Berdasarkan Nursing Intervension Classiication (NIC) Domain physiological ; basic, ada berbagai macam upaya relaksasi diantaranya teknik napas dalam, relaksasi otot progresif, diharapkan dapat menstimulasi saraf parasimpatis yang akan meredakan ketegangan otot, vasodilatasi, dan yang paling utama adalah dapat mengatasi kelelahan.

\section{Analisis Bivariat}

Tabel 4. Tekanan Darah Responden yang Diberikan Terapi Foot Massage dan Progressive Muscle Relaxation di Wilayah Kerja Puskesmas Ogan Lima Kabupaten Lampung Utara Tahun 2020

\begin{tabular}{lllll} 
& & & $n=18$ \\
\hline Variabel & Mean & SD & SE & P value \\
\hline Foot massage & & & & \\
TD sebelum & $153,33 / 101,11$ & $14,142 / 10,541$ & $4,714 / 3,514$ & $0,008 / 0,003$ \\
TD Setelah & $145,56 / 91,11$ & $16,667 / 10,541$ & $5,556 / 3,514$ & \\
Progressive musle relaxation & & & \\
TD sebelum & $154,44 / 98,89$ & $13,333 / 7,817$ & $4,444 / 2,606$ & $0,013 / 0,041$ \\
TD Setelah & $143,33 / 95,56$ & $14,142 / 8,819$ & $4,174 / 2,940$ & \\
\hline
\end{tabular}

\section{${ }^{*} p<0,05$, paired $t$-test}

Berdasarkan tabel 4 didapatkan nilai $t$ hitung untung tingkat kelelahan sebesar 11,249 dengan pvalue sebesar 0,000 terlihat bahwa $p$ value kurang dari a $(0,05)$. Hal ini menunjukan bahwa ada perbedaan bermakna terhadap penurunan tingkat kelelahan pasien gagal jantung sebelum dan sesudah diberika terapi Emotional Freedom technique (EFT). 
Tabel 5. Kecemasan Responden yang Diberikan Terapi Foot Massage dan Progressive Muscle Relaxation di Wilayah Kerja Puskesmas Ogan Lima Kabupaten Lampung Utara Tahun 2020

\begin{tabular}{ccccc}
\multicolumn{1}{c}{ Variabel } & Mean & SD & SE & P value \\
\hline Foot Massage & & & & \\
$\quad$ Cemas sebelum & 19,67 & 5,099 & 1,700 & 0,003 \\
$\quad$ Cemas Setelah & 15,56 & 5,102 & 1,701 & \\
Progressive Muscle Relaxation & & & \\
$\quad$ Cemas sebelum & 18,44 & 3,644 & 1,215 & 0,019 \\
$\quad$ Cemas Setelah & 15,78 & 3,232 & 1,077 & \\
${ }^{*} p<0,05$, paired $t$-test & & & &
\end{tabular}

Tabel 6. Perbedaan Tekanan Darah Responden yang Diberikan Terapi Foot Massage Dan Terapi Progressive Muscle Relaxation di Wilayah Kerja Puskesmas Ogan Lima Kabupaten Lampung Utara Tahun 2020

\begin{tabular}{|c|c|c|c|c|c|}
\hline Variabel & Mean & SD & $t$ & $p$ value & $95 \% \mathrm{Cl}$ \\
\hline Sistole & 153,33 & 14,142 & \multirow{3}{*}{0,171} & \multirow{3}{*}{0,866} & \multirow{3}{*}{$14,846-12,623$} \\
\hline sebelum FM & & & & & \\
\hline $\begin{array}{c}\text { Sistole } \\
\text { sebelum PMR }\end{array}$ & 154,44 & 13,333 & & & \\
\hline Diastol & 101,11 & 10,541 & \multirow{3}{*}{0,508} & \multirow{3}{*}{0,618} & \multirow{3}{*}{$7,051-11,496$} \\
\hline sebelum FM & & & & & \\
\hline $\begin{array}{c}\text { Diastole } \\
\text { sebelum PMR }\end{array}$ & 98,89 & 7,817 & & & \\
\hline Sistole & 145,56 & 16,667 & \multirow{3}{*}{0,305} & \multirow{3}{*}{0,764} & \multirow{3}{*}{$13,223-17,668$} \\
\hline setelah FM & & & & & \\
\hline $\begin{array}{c}\text { Sistole } \\
\text { setelah PMR }\end{array}$ & 143,33 & 14,142 & & & \\
\hline Diastole & 91,11 & 10,541 & \multirow{3}{*}{0,970} & \multirow{3}{*}{0,346} & \multirow{3}{*}{$14,156-5,267$} \\
\hline setelah FM & & & & & \\
\hline $\begin{array}{c}\text { Diastole } \\
\text { setelah PMR }\end{array}$ & 95,56 & 8,819 & & & \\
\hline \multicolumn{6}{|c|}{${ }^{*} p<0,05$, independent $t$-test } \\
\hline $\begin{array}{l}\text { Berdasarkan } \mathrm{t} \\
\text { nilai t hitun } \\
\text { kelelahan sebes } \\
\text { value sebesar } 0 \\
\mathrm{p} \text { value kurang }\end{array}$ & $\begin{array}{l}\text { el di } \\
\text { untung } \\
11,249 \\
00 \text { terlih } \\
\text { ri a }(0,0\end{array}$ & $\begin{array}{l}\text { atkan } \\
\text { ingkat } \\
\text { yan p- } \\
\text { Jahwa } \\
\text { tal ini }\end{array}$ & \multicolumn{3}{|c|}{$\begin{array}{l}\text { menunjukan bahwa ada perbedaan } \\
\text { bermakna terhadap penurunan } \\
\text { tingkat kelelahan pasien gagal } \\
\text { jantung sebelum dan sesudah } \\
\text { diberika terapi Emotional Freedom } \\
\text { technique (EFT). }\end{array}$} \\
\hline
\end{tabular}


Tabel 7. Perbedaan Tingkat Kecemasan Responden yang Diberikan Terapi Foot Massage dan Progressive Muscle Relaxation di Wilayah Kerja Puskesmas Ogan Lima Kabupaten Lampung Utara Tahun 2020

\begin{tabular}{|c|c|c|c|c|c|}
\hline Variabel & Mean & SD & $t$ & $p$ value & $95 \% \mathrm{Cl}$ \\
\hline Cemas sebelum FM & 19,67 & 5,099 & & & \\
\hline $\begin{array}{c}\text { Cemas sebelum } \\
\text { PMR }\end{array}$ & 18,44 & 3,644 & 0,585 & 0,567 & $3,206-5,651$ \\
\hline Cemas setelah FM & 15,56 & 5,102 & & & \\
\hline $\begin{array}{c}\text { Cemas setelah } \\
\text { PMR }\end{array}$ & 15,78 & 3,232 & 0,110 & 0,913 & $4,490-4,045$ \\
\hline
\end{tabular}

Berdasarkan tabel 4 didapatkan nilai $t$ hitung untung tingkat kelelahan sebesar 11,249 dengan $\mathrm{p}$ value sebesar 0,000 terlihat bahwa $p$ value kurang dari a $(0,05)$. Hal ini

\section{PEMBAHASAN \\ Analisa Univariat}

Berdasarkan hasil penelitian diperoleh responden yang mengalami kelelahan berat sebanyak 11 orang $(73,3 \%)$. hal ini disebabkan kegagalan jantung mempertahankan sirkulasi yang menyebabkan terhambatnya aliran darah dan nutrisi jaringan sehingga akan mengganggu perfusi jarngan dan meningkatkan tekanan vaskuler perifer. . manifestasi kelelahan adalah penurunan kapasitas fisik maupun psikis dalam melakukan aktivitas sehari-hari. Selain itu perasaan tidak berdaya merupakan salah satu manifestasi yang memperburuk pasien gagal jantung secara psikologis.

Dilihat dari rata-rata tingkat kelelahan sebelum dan sesudah intervensi EFT terlihat adanya penurunan tingkat kelelahan. Ratarata sebelum intervensi sebesar 21,27 dan termasuk dalam kriteria kelelahan berat. Setelah intervensi EFT nilai rata-rata kelelahan pasien gagal jantung mengalami penurunan menunjukan bahwa ada perbedaan bermakna terhadap penurunan tingkat kelelahan pasien gagal jantung sebelum dan sesudah diberika terapi Emotional Freedom technique (EFT).

menjadi 26,40 . Tetapi nilai 26,40 masih termasuk dalam kriteria kelelahan berat. Faktor usia dan jenis kelamin menjadi faktor predisposisi yang dapat memperburuk kondisi pasien gagal jantung. Penderita berjenis kelamin perempuan lebih banyak menderita gagal jantung dikarenakan perempuan mengalami penurunan kadar hormon estrogen yang berakibat meingkatnya kadar kolesterol LDL yang berimbas pada peningkatan kadar kolesterol plasma. LDL yang teroksidasi yang akan merusak dinding vaskuler dan akan membentuk aterosklerosis yang berujung pada hipertensi. Faktor usia juga memperburuk prediksi penerita gagal jantung. Seseorang yang berusia >40 tahun akan mengalami proses penuaan yang akan berimbas pada penurunn fungsi jantung.

Pasien usia lanjut seringkali mengalami polifarmaka yang mengarah pada penurunan fungsi hati dan ginjal sehingga menurunkan ketersediaan energi 
untuk beraktifitas mengingat kedua kondisi tersebut akan memicu respon inflamai kronis yang disertai dengan peningkatan konsentrasi mediator terutama sitokin. Peningkatan sitokin akan menyebabkan kelelahan. Penelitian terbaru yang dilakukan oleh Banerjee pada 423 pasien yang mengalami gagal jantung membuktikan bahwa faktor umur berpengaruh secara signifikan ( $p$ value $=0,000$ ) sebesar $54 \%$ terhadap kualitas hidup pasien (Akhmad, Primanda,\& Istanti, 2016).

Menurut asumsi peneliti, penatalaksanaan non farmakologis juga harus dilaksanakan pada pasien gagal jantung. Penatalaksanaan farakologis antara lain dengan menjelaskan kepada pasien mengenai penyakitnya, pengobatan serta pertolongan yang dapat dilakukan sendiri. Perubahan gaya hidup seperti pengaturan nutrisi, penurunan berat badan, konsumsi alkohol serta pembatasan asupan cairan perlu dianjurkan pada penderita terutama pada kasus gagal jantung berat. Ketidaktahuan atau ketidakmampuan pasien dan keluarga mengenai cara perawatan di rumah juga berdampak pada masalah kesehatan atau ketidaksiapan merawat pasien gagal jantung. Pasien gagal jantung harus bisa menjaga kesehatan seperti membatasi aktivitas fisik, mengatur pola makan serta menghindari gaya hidup yang tidak sehat seperti kebiasaan merokok. Jika hal tersebut dapat dilaksanakan maka akan mengrangi tingkat kelelahan pasien gagal jantung yang pada akhirnya akan meningkatkan kualitas hidup pasien gagal jantung.

\section{Analisa Bivariat}

Hasil uji statistik dengan uji Paired test diperoleh $t$ hitung untung tingkat kelelahan sebesar $11,249 \mathrm{p}$-value $=0,000$ yang berarti ada pengaruh intervensi Emotional Freedom Technique (EFT) terhadap tingkat kelelahan pasien gagal jantung di Puskesmas Hanura Tahun 2020.

Hasil penelitian ini sejalan dengan panatalaksanaan penderita gagal jantung meliputi penatalaksanaan secara non farmakologis dan farmakologis, keduanya dibutuhkan karena akan saling melengkapi untuk penatalaksanaan gagal jantung baik itu akut maupun kronis ditujukan untuk memperbaiki gejala dan prognosis, meskipun penatalaksnaan secara individual tergantung dari etiologi serta beratnya kondisi. Sehingga semakin cepat kita mengetahui penyebab gagal jantung akan semakin baik prognosisnya. Salah satu teknik non farmakologis yang dapat dilakukan dalam intervensi keperawatan adalah teknik relaksasi.

Menurut analisis peneliti, dapat diartikan bahwa teknik relaksasi berupa Emotional Freedom Technique (EFT) berpengaruh terhadap penurunan tingkat kelelahan pada pasien gagal jantung di Puskesmas Hanura. Terapi EFT merupakan mind body therapy. Terapi ini menggabungkan ketukan ringan (tapping) pada titik-titik meridian tubuh. Dan pada fase setup, yang dapat diartikan sebagai doa. Dengan doa timbul rasa amat dekat yang tidak akan membuatnya sedih. Nilai ibadah sangat penting dalam megurangi tekanan emosional sehingga berpengaruh pada proses terjadinya kelelahan. Motivasi dan sikap beribadah yang ikhlas dapat dijadikan alternatif sebagai psikoterapi yang dapat menstabilkan hormon stres. Adanya sugsti dalam bentuk kalimat afirmasi yang diucapkan oleh diri sendiri secara sadar, mengalir serta ikhlas dapat menetralkan pikiran negatif di dalam otak. Dengan 
adanya sugesti positif yang dibarengi dengan tapping dapat menghilangkan psychological reversal pada seseorang dengan penyakit gagal jantung, terutama untuk meredakan kecmasa yang akan menyebabkan respon simpatis serta menjadi salah satu faktor yang menyebabkan terjadinya kelelahan berkaitan dengan perubahan neurohormonal pada penderita gagal jantung.

Menurut Nugraha, Fatimah \& Kurniawan (2017) bahwa teknik relaksasi akan menstimulasi sekresi endorfin di otak. Relaksasi akan memicu pengeluaran hormon endorfin. Hormon tersebut berbentuk polipeptida yang mengandung 30 unit asam amino yang mengikat reseptor opiat di otak. Hormon ini bertindak seperti morphine, bahkan dikatakan 200 kali lebih efektif dari morphine. Endorfin mampu menimbulkan perasaan euforia, bahagia, nyaman, menciptakan, ketenangan dan memperbaiki suasana hati seseorang hingga membuat seseorang rileks. Relaksasi akan memicu limbik sistem dan memicu hipotalamus untuk mensekresikan endorfin. Dalam kondisi tersebut, maka konsentrasi endorfin di otak akan meningkat.

Hasil penelitian ini sejala dengan penlitian Isworo, Anam, \& Indrawati (2019) yang menyatakan yang menyatakan ada perbedaan yang bermakna TDS sebelum dan setelah dilakukan terapi EFT $(p<0,01)$, tetapi tidak ada perbedaan yang bermakna pada TDD pada kelompok intervensi $\quad(p=0,699)$. Pada kelompok kontrol baik TDS maupun TDD tidak ada perbedaan bermakna sebelum dan sesudah perlakuan $(p=0,343), \quad(p=0,620)$. Perbaikan kondisi psikologis pada pasien gagal jantung mengarah pada penurunan skor kelelahan terlebih jika diikuti dengan perbaikan pada parameter fisiologis. Teknik relaksasi dapat mempengaruhi prameter fisiologis seperti tekanan darah, nadi, frekuensi pernapasan, suhu dan saturasi oksigen. Perbaikan kondisi psikologis setlah EFT mengarah pada teratasinya kelelahan pada pasien gagal jantung.

Analisis peneliti berdasarkan hasil penelitian ini menunjukkan bahwa rerata tingkat kelelahan sesudah terapi lebih rendah dibandingkan sebelum diberikan intervensi EFT, hal ini berarti bahwa terapi EFT efektif untuk menurunkan tingkat kelelahan pada pasien gagal jantung. Manfaat EFT pada pasien dengan gagal jantung selain untuk mengatasi kelelahan adalah untuk menekan kecemasan yang merupakan salah satu prediktor terjadinya kelelahan pada pasien gagal jantung. Penurunan skor kecemasa akan menciptakan kenyamanan fisik dan psikologis. Dengan meningkatnya kenyamanan, maka kualitas istirahat pasin akan lebih baik sehingga proses konservasi energi akan lebih optimal. Manfaat berikutnya adalah penurunan beban kerja jantung pada fase after load dikarenakan vasodilatasi pembuluh darah dan penurunan tekanan darah pada pasien gagal jantung setelah dilakukan intervensi. Gangguan fisik pada pasien gagal jantung yang cenderung menetap terutama gangguan pada struktur jantung yang tidak dapat diatasi dengan teknik EFT. Akan tetapi, gangguan yang sifatnya psikis dapat diatasi dengan EFT. Hal ini dapat dibuktikan dengan penurunan tingkat kelelahan pada pasien gagal jantung. 


\section{KESIMPULAN}

Dari penelitian yang dilakukan di Puskesmas Hanura tahun 2020, dengan judul "Pengaruh Emotional Freedom Technique (EFT) terhadap Penurunan Tingkat Kelelahan Gagal Jantung" dapat disimpulkan sebagai berikut:

1. Distribusi frekuensi jenis kelamin responden perempuan sebanyak 12 responden (80\%), berusia lebih dari 60 tahun sebanyak 9 responden $(26,7 \%)$, responden berpendidikan SD sebanyak 5 orang $(35,7 \%)$ dan responden yang mengalami kelelahan berat sebanyak 11 responden $(73,3 \%)$.

2. Rata-rata tingkat kelelahan pasien gagal jantung di Puskesmas Hanura sebelum terapi Emotional Freedom Technique (EFT) sebesar 21,27 dengan standar deviasi 9.384.

3. Rata-rata tingkat kelelahan pasien gagal jantung di Puskesmas Hanura sesudah terapi Emotional Freedom technique (EFT) sebesar 26,40 dengan standar deviasi 8,441.

DAFTAR PUSTAKA

Akhmad, A.N. (2018). Kualitas Hidup Pasien Gagal Jantung Kongestif (GJK) berdasarkan

Karakteristik Demografi. Jurnal Keperawatan Siedirman, 11 (1), 27-34.

Aprina, A., \& Anita, A . (2017) Riset Keperawatan. Tidak dipublikasikkan.

Bach,D., Groesbeck, g., Stapleton,p., Sims, R., Blickheuser, K., \& Crurch,D.(2019). Clinical EFT(emotional Freedom techniques) improves multiple Physiological markers of Health. Jurnal
4. Ada pengaruh antara pemberian terapi Emotional Freedom Technique terhadap penurunan tingkat kelelahan pasien gagal jantung di Puskesmas Hanura Kabupaten Pesawaran Tahun 2020 (p-value $=0,000)$.

\section{Saran}

1. Bagi institusi pendidikan keperawatan

Penelitian ini dapat dijadikan salah satu literatur untuk proses pembelajaran tentang Emotional Freedom technique (EFT) dan fatique pada pasien gagal jantung pada mata kuliah keperawatan medikal bedah.

2. Bagi pelayanan Kesehatan Berdasarkan penelitian ini, maka teknik Emotional Freedom Technique (EFT) dapat diaplikasikan dalam kegiatan puskesmas misalnya kegiatan PROLANIS puskesmas untuk mengatasi kelelahan pada pasien gagal jantung.

of Evidence-based integrative medicine, 24, $2515690 \times 8823691$.

Brahmantia, B., \& Huriah, T. (2018). Pengaruh Spiritual Emotional Freedom technique (SEFT) terhadap Penurunnan Nyeri dan Kecemasan pada Pasien Pasca Bedah Transurethral resection prostate (TURP) di RSUD dr.Soekardjo Kota Tasikmalaya. Jurnal Kesehatan karya Husada, 6(2), 160-177

Clond, M. (2016). Emotional freedom techniques for anxiety: a systematic 
review with metaanalysis. The Jurnall of nervous and mental disease, 204(5), 388-395.

Dewanti, G . S ., \& Hudiyawati, D. (2019).Gambaran

Aktivitas Fisik pada Pasien Gagal Jantung (Doctoral disertation, Universitas

Muhammadiyah Surakarta)

Djamaludin,D., Tua,R., \& Deria,D. (2018). Hubungan Self Care Terhadap Kualitas Hidup pada Klien Gagal Jantung di Poli Jantung RSUD Dr. H. Abdul Moeloek Provinsi Lampung Tahun 2017. Holistik Jurnal kkesehatan,12(3), 178188

Fatmawati, D . (2018). Spiritual Emotional Freedom technique (SEFT) untuk menurunkan Stress Pada Pasien Hipertensi (Dictoral dissertation, Universitas Mercu Buaana Yogyakarta).

Isworo, A., Anam, A.,\& Indrawati, N. (2019). Pengaruh terapi Emotional Freedom technique (EFT) dalam Menurunkan Tekanan darah pada Lansia Hipertensi. Gaster: Jurnal Kesehatan, 17(2), 154-166.

Kemenkes, R.I. (2018). Hasil utama RISKESDAS 2018. Online http:

//www.depkes.go.id/res ources/download/infoter kini/materi_rakorpop_20 18/Hasil\%20Riskesdas,20 20218.

Kristinawati,BB.,\& Khasanah, R.N. (2019). Hubungan Pelaksanaan Edukasi dengan KemampuanSelf
Care Management Pasien Gagal Jantung. Proceeding of the URECOL, 496-503.

Latifah, L., \& Ramawati, D. (20180. Intervensi Emotional Freedom technique (EFT) untuk MengurangiNyeri Post Operasi Sectio Caesaria (SC). Indonesian Nursing Journal of Education and Clinic (INJEC), 1 (1), 53-60

Majid, A. (2017). Asuhan keperawatan pada Pasien dengan Gangguan Sistem Kardiovaskuler.

Masengi, K. G., OngkowijY, J ., \& Wantania., F (2016). Hubungan Hipeurisemia dengan kardiomegali pada Pasien Gagal Jantung Kongestif.e.Clinic, 4 (1). Nirmalasari, N. (2017). Deep Breathing exercises and Active Range of Motion Effectively Reduce Dyspnea in Congestive Heart Failure Patients. Nureseline Journal, 2 (2), 159-165

Nugraha, B.A. (2016). Fatique pada Pasien Gagal Jantung."Jurnal Medika Cendikia, 3 (01), 58-67.

Nugraha, B.A. (2018, August). Kelelahan pada Pasien dengan Penyakit Kronis . In prosiding Seminar Bakti Tunas Husada (vol 1, No.1).

Nugraha, B.A., Fatimah, S., \& Kurniawan ,T. (2017). Pengaruh Pijat Punggung terhadap Skor Kelelahan Pasien Gagal Jantung. Jurnal keperawatan pandjjadjaran, 5 (1).

Nugraha, B.A.,Pebrianti,S .,\& Platini, H. (2018). Gambaran Kelelahan 
pada Pasien Gagal Jantung. Jurnal Medika Cendikia, 5(01), 16-21.

Nurarif, A.H., Kusuma H . (2015). Aplikasi Asuhan Keperawatan

Berdasarkan Diiagnosa Medis \& NANDA (North American Nursing Diagnosis Association) Nic-Noc.

Pudiarifanti,N. Pramantara, I.D., \& Ikawati,Z. (2015). Faktorfaktor yang Mempengauhi Kualitas Hidup Pasien Gagal Jantung kronik. Jurnal Manajemen dan Pelayanan Farmasi (Jurnal of Management and Pharmacy Practice), 5 (4), 259.266.

Rahmayanti, N. S., \& Ariguntar, T. (2017). Karakteristik Responden dalam Penggunaan Jaminan kesehatan Pada Era BPJS di Puskesmas Cisoka Kabupaten Tangerang Januari -Agustus 2015. Jurnal Medicoeticolegal dan Manajemen Rumah Sakit, 6(1), 61-65.

Rofacky, H. F., \& Aini, F. (2015). Pengaruh Terapi Spiritual Emotional Freedom Technique (SEFT) terhadap tekanan Darah penderita Hipertensi. Jurnal Keperawatan Soedirman, 10(1), 41-52

Sihombing, J . P., Hakim, L., Andayani, T . M . , \& Irijanto, F. (2016). Validasi Kuisioner Skala Kelelahan FACIT pada Pasien Gagal Ginjal Kronis yang Menjalani Hemodialisis Rutin. Indonesian Journal of
Clinical Pharmacy,5(4), 231-237.

Susilo. M.H. (2019). Terapi Depresi Tekhnik Kilat melepaskan masalah dan Emosi menggunakan Metode Sederhana EFT (Emotional Freedom Technique). Psikologi Corner. Yogyakarta.

Tennant, K. (2015). Assessment of Fatique in older adults: The FACIT Fatique Scale (version 4). Suppportive Care in Cancer, 23 (5), 1355-1364.

Thahir, A., Sulastri., \& Almurhan, A. (2016). Emotional Freedom Techique. Jurnal kesehatan, 5 (1).

Trisnawati, N. (2018). Terapi Akupressur untuk Mengatasi Fatique pada pasien dengan Gagal Ginjal Kronik dengan Hemodialisa di Rumah sakit islam Purwokerto (Doctoral dissertation, Universitas Muhammadiyah Purwokerto).

Trisnawati, N., Pebriyani, U., \& Gemilang, I . (2016). Hubungan Hipertensi dengan Kejadian Penyakit Gagal Jantung Kongestif di Rumah Sakit Pertamina Bintang Amin provinsi Lampung. Jurnal IImu kedokteran dan kesehatan, 3 (4)

Widagdo, F., Karim, D., \& Novayellinda, R. (2015). Faktor-faktor yang Berhubungan dengan Kejadian Rawat Inap Ulang Di Rumah Sakit pada Pasien Chf (Doctoral dissertation, Riau Universit. 